\title{
Analysis of generation means for some metric plant traits in two wheat (Triticum aestivum L.) hybrids
}

\author{
Shahzadi Mahpara ${ }^{*}$, Syed Tahir Hussain ${ }^{1}$, Javaid Iqbal ${ }^{2}$, Ijaz Rasool \\ Noorka $^{3}$ and Said Salman ${ }^{1}$ \\ 1. Department of Plant Breeding \& Genetics, Faculty of Agricultural Sciences, Ghazi University, D.G. Khan- \\ Pakistan \\ 2. Department of Agronomy, Faculty of Agricultural Sciences, Ghazi University, D.G. Khan-Pakistan \\ 3. Department of Plant Breeding \& Genetics, University College of Agriculture, University of Sargodha-Pakistan \\ *Corresponding author's email: mahpara.gudgk@gmail.com
}

Citation

Shahzadi Mahpara, Syed Tahir Hussain, Javaid Iqbal, Ijaz Rasool Noorka and Said Salman. Analysis of generation means for some metric plant traits in two wheat (Triticum aestivum L.) hybrids. Pure and Applied Biology. Vol. 7, Issue 1, pp93-102. http://dx.doi.org/10.19045/bspab.2018.70012

\begin{tabular}{llll}
\hline \hline Received: 29/09/2017 & Revised: 26/12/2017 & Accepted: 31/12/2017 & Online First: 10/01/2018 \\
\hline \hline
\end{tabular}

\section{Abstract}

An experiment was done at Department of Plant Breeding \& Genetics, Ghazi University, D. G. Khan to find out genetic effects for some quantitatively inherited plant traits using six generations viz., parents, their first and second filial generations and their backcrosses of two wheat crosses like Mairaj-08 $\times$ Blue Silver as cross-I and Faisalabad-08 $\times$ DH-60 as cross-II. Through scaling, analysis on generation means was performed and involvement of epistasis was found for many plant traits in both cross combinations. So, a model of six parameters was applied for estimation of nature of genetic interaction in all plant characters excluding 1000-grains weight. Additive gene action was controlling yield and yield related traits in both cross combinations. So, it was found that many plant traits in cross combination like Faisalabad- $08 \times \mathrm{DH}-60$ were controlled by additive genetic effects so this cross can be utilized in future wheat improvement program for high yield.

Keywords: Additive gene action; Epistasis; Generation mean analysis; Gene action; Grain yield; Plant traits; Wheat

\section{Introduction}

Among all cereal crops, wheat is an imperative and diversified grain crop. Globally, it provides dietary requirements of about $30 \%$ people and about $50 \%$ food calories and protein requirements were provided for the humans. Due to its importance, wheat is consumed as food on daily basis in Pakistan. As wheat is a major crop in Pakistan but it was grown on 9.05 million hectares with average yields 2. 845 $\mathrm{kg}$ per hectare [1] which requires to be improved for swiftly growing population. So, it is crucial to increase per acre yield by exploring and utilizing existing wheat germplasm to produce new and improved genetic material having potential for wider adaptability [2-4] and it can be effectively utilized in Pakistan.

Yield is a plant attribute that is controlled by multigenes and these features are integrated in connections of genotypic and natural change. In a hereditary populace, hereditary variations and genetic study 
decides the behavior and expression of genes [5]. Breeding for improved grain yield is a complex process if yield is the only factor, so it is recommended that its related characteristics can be utilized as determination criteria for yield change. So, knowledge about inheritance of yield related traits is also important in this case [6]. Impacts of genes including mean (m), additive $(\mathrm{d})$ and predominance $(\mathrm{h})$ and three different non-allelic interactions viz., additive $\times$ additive (i), additive $\times$ dominance $(j)$ and dominance $\times$ dominance (1) are vital. Generation means investigation is one of the consistent biometrical techniques. It is an extremely valuable to calculate genetic effects and genetic interactions controlling yield and its related traits [7]. Acquiring of genetic information from many generations are more consistent than those taken from one generation. So, all six generations including both parents, first and second filial generations and back cross- 1 and back cross-11 provide detailed genetic information for varieties under study. $[8,9]$ found that additive-dominance model were adequate for revealing the inheritance of grain yield and its components. With A, B, C and $\mathrm{D}$. scaling tests, additive, dominance and epistatic effects were important for yield and its components characters. Some studies on generation mean analysis found additive and dominance genetic factors were important for most of plant traits in wheat [10].

Present study was made to get information about genetic heritability and genetic effects and gene action for different plant attributes in two wheat cross combinations. This information can be utilized for further wheat development program to improve grain yield. Thus, present study was carried out to get information about genetic variability, gene action and genetic interaction for various plant traits in two wheat crosses. Findings of these studies can be used for further wheat breeding program to enhance grain yield.

\section{Materials and methods Plant materials}

Two spring wheat (Triticum aestivum L.) cross combinations like Mairaj-08 $\times$ Blue silver and Faisalabad-08 $\times$ DH-60 were grown as experimental materials in this experiment.

Seeds of all parental varieties and their first filial generations for both crosses were supplied by the Department of Plant Breeding and Genetics, Ghazi University, D. G. Khan and $F_{2}$ (by selfing of $F_{1}$ plants), $B_{1}$ and $\mathrm{BC}_{2}$ plant populations were developed by hybridization process between plants of $F_{1}$ and $\mathrm{P}_{1}$ and $\mathrm{P}_{2}$. When plants become mature, seeds of each generation were kept separately for next year. In this way, seeds of each of the six populations (parent cultivars $\left(\mathrm{P}_{1}, \mathrm{P}_{2}\right)$, first and second filial progenies $\left(\mathrm{F}_{1}, \mathrm{~F}_{2}\right)$, first and second backcrosses $\left(\mathrm{BC}_{1}, \mathrm{BC}_{2}\right)$ of both crosses were planted in a complete randomized block manner in three replications at Department of Plant Breeding \& Genetics, Faculty of Agricultural Sciences, Ghazi University, D. G. Khan. Every line consisted of 2 meter length and distance between plants and rows were maintained 10 $\mathrm{cm}$ and $30 \mathrm{~cm}$ respectively. During maturity, information were gathered on different plant characteristics like days to heading, days to maturity, plant height $(\mathrm{cm})$, number of tillers/pant, peduncle length $(\mathrm{cm})$, spike length $(\mathrm{cm})$, number of spikelet per spike, spike density, number of grains per spike, 1000-grain weight (g), grain yield per plant (g).

Information collected for these traits was subjected for analysis of variance as portrayed by [11] to find variations between all six generations of both cross combinations. Means for each of six generations were assessed by LSD test for all studied traits before biometrical investigation and then scaling tests (A, B, C and D) were 
carried out to identify involvement of epistasis as indicated by [12]. If epistasis was present, analysis for estimation of non-allelic interaction was done for estimation of six parametric models of inheritance viz., M, D, $\mathrm{H}, \mathrm{I}, \mathrm{J}$, and L as mentioned by [13]. The basic genetic model (M, D, and $\mathrm{H}$ ) was used when there was no epistasis in any trait.

\section{Results and discussion}

Analysis of variance (ANOVA) was done on the basis of data collected for both crosses for different plant qualities. Mairaj-08 $\times$ Blue Silver cross in (Table 1) indicated significant variant for each of six families $(\mathrm{P} \leq 0.01)$ for different plant characteristics viz., days to heading, plant height, number of tillers per plant, peduncle length, spike length, number of spikelets per spike, spike density, number of grains per spike, 1000-grain weight, grain yield per plant excluding days to maturity. Table 2 demonstrated presence of hereditary variation in Faisalabad-08 $\times$ DH-60 for all plant traits studied. Both crosses along with all six generations indicated that they were genetically different for plant traits under discussion.

Genetic variability was also found in wheat for various quantitative plant traits by [1425]. Presence of genetic variation indicated for proceedings of genetic analysis for studied plant traits.

\section{Scaling tests}

As analysis of variance for both crosses indicated dissimilarities for all genotypes for plant traits studied, generation men analysis was carried out for assessment of gene action for different plant attributes. Analysis of generation means having scaling test is very important to find out either non-allelic gene action is present or not and which model for this analysis is suitable. Four kinds of scaling tests were suggested by [12]. In case of significance of any scaling test, it shows the presence of epistasis for that plant trait. While a situation in which all scaling tests are not significant so epistasis is absent and a model of three parameters is applicable. A model of six parameters is applicable in this situation for determination of heredity effects and gene action.

Results in (Table 3) also indicated that in Mairaj-08 $\times$ Blue Silver cross, every one of four scaling tests (A, B, C and D) were important for plant attributes like days to heading, number of tillers per plant, number of spikelets per spike, spike length and spike density. But scaling tests A, B and D with values $\quad(27.03 *, 14.61 *,-19.83 *) \quad$ were significant for days to maturity and plant height had significant $\mathrm{A}, \mathrm{C}$ and $\mathrm{D}$ scaling tests with values $5.96^{*}, 13.57^{*}$ and $3.62^{*}$ respectively.

While in grain yield per plant, both scaling tests $\mathrm{A}$ and $\mathrm{C}$ were important. Similarly, for number of grains per spike, ' $\mathrm{C}$ and $\mathrm{D}$ scaling tests were essential while significant scaling tests 'A and D' were found for peduncle length. Each of these attributes showed epistasis type of gene action because of significance of scaling tests for all traits except for 1000-grains weight which possessed non-significant results for scaling tests. So in 1000-grains weight, epistasis was absent.

Scaling tests in cross Faisalabad-08 $\times$ DH60 for plant height and peduncle length (Table 4) indicated that all types of scaling tests (A, B, C and D) were found important. While scaling tests $\mathrm{A}, \mathrm{B}$ and $\mathrm{C}$ were proved crucial for days to heading and days to maturity plant traits. A, C and D types of scaling tests were observed as vital for spike density. Similarly, A and D scaling tests were important for number of tillers per plant and spike length. But scaling tests like B and C were important for plant traits like number of spikelets per spike, number of grains per spike and 1000-grains weight. But grain yield per plant trait was important due to significance of $\mathrm{A}$ and $\mathrm{C}$ types of scaling tests. Similar results were found by $[26,27]$ when they worked on wheat. 


\section{Estimation of genetic components}

To determine the genetic effects like additive, dominance and their interactions with each other, generation means analysis is mostly utilized. So, scaling tests were utilized to find out to appraise the existence of epistasis. Any scaling test found significant for any plant trait it corroborates involvement of epistasis. For further study, a six parametric model for analysis of generation means is functional in case of significance of any scaling test.

Result for estimation of genetic effects in model of six parametric was given in (Table 5). As scaling tests were valuable for plant traits studied in first cross (Mairaj-08 $\times$ Blue Silver). So, six parametric model was desirable for all plant traits except for 1000grains weight which was non-significant for scaling tests so a model of three parameters was applied for estimation of genetic interaction and genetic effects. Similarly in $2^{\text {nd }}$ cross (Faisalabad-08 $\times$ DH-60) as scaling tests for all traits under study were found vital so for these traits, a six parametric model was used for determination of genetic effects.

The results in (Table 5) indicated that mean effects (M) for studied plant traits were important and additive genetic effects (D) were also significant either these are in positive or negative values most of plant traits like days to heading, peduncle length, spike length, number of spikelets per spike, 1000 -grains weight in first cross. But in second cross, additive type genetic effects (D) were crucial for most of plant traits including days to heading, days to maturity, plant height, peduncle length, spike density. Many plant characters were found to be important for dominance genetic effects in Mairaj-08 $\times$ Blue Silver cross. While in second cross, many plant traits were vital for dominance genetic effects. It suggests that possible progress in wheat can be made by selecting progenies of the cross (Faisalabad$08 \times$ DH-60). Similarly, the values of 'H' was greater than that of ' $D$ ' in this cross which proposed utilization of pedigree method of selection after hybridization as best method for population improvement in selfpollinated crop plants. Similar findings were given by [28-31].

Estimates of non-allelic genetic effects were also observed where significant additive $x$ additive type (I) of epistasis was found for all studied traits except for 1000-grains weight and grain yield per plant in cross-1 (Mairaj$08 \times$ Blue Silver). It is important to mention here that six parameters model was not applied on 1000-grain weight trait due to non-significance of all scaling tests in this cross so, indirect selection of plant for this traits is recommended but ' $\mathrm{I}$ ' type genetic effects for second cross were played an important role in inheritance of days to maturity, plant height, peduncle length and spike density and it showed that these plant traits had increasing the genes selection of plants for these trait can be effectual. Gene effect ' $J$ ' (Additive $\times$ dominance epistasis) exhibited significant result for most of plant traits in both crosses but some plant traits like number of spikelets per spike and grain yield per plant were found non-significant and was also found as negative in days to heading, number of spikelets per spike, spike density for same cross.

Number of tillers per plant, spike length, number of spikelets per pike, number of grains per spike and 1000-grains weight for cross-II were also found negative in gene effect ' $J$ ' which showed genes for these traits were dispersed for these traits in parents. 
Table 1. Analysis of variance for yield and its related traits in Mairaj- $08 \times$ Blue silver cross

\begin{tabular}{|c|c|c|c|c|c|c|c|c|c|c|c|c|}
\hline S.O.V & DF & $\begin{array}{l}\text { Days to } \\
\text { heading }\end{array}$ & $\begin{array}{l}\text { Days to } \\
\text { maturity }\end{array}$ & $\begin{array}{l}\text { Plant } \\
\text { height }\end{array}$ & $\begin{array}{c}\text { Peduncle } \\
\text { length }\end{array}$ & $\begin{array}{l}\text { No. of } \\
\text { tillers/ } \\
\text { Plant }\end{array}$ & $\begin{array}{l}\text { Spike } \\
\text { length }\end{array}$ & $\begin{array}{c}\text { No. of } \\
\text { spikelet/ } \\
\text { spike }\end{array}$ & $\begin{array}{c}\text { Spike } \\
\text { density }\end{array}$ & $\begin{array}{c}\text { No. of } \\
\text { grains/ } \\
\text { spike } \\
\end{array}$ & $\begin{array}{c}\text { 1000- } \\
\text { grain wt. }\end{array}$ & $\begin{array}{l}\text { Grain } \\
\text { yield/ } \\
\text { plant }\end{array}$ \\
\hline Blocks & 2 & $14.57 * *$ & $7.60 * *$ & $2.31^{\mathrm{ns}}$ & $1.57^{\mathrm{ns}}$ & $0.30^{\mathrm{ns}}$ & $2.89^{\mathrm{ns}}$ & $2.50^{\mathrm{ns}}$ & $0.01^{\mathrm{ns}}$ & $1.03^{\mathrm{ns}}$ & $0.52^{\mathrm{ns}}$ & $1.32^{\mathrm{ns}}$ \\
\hline Generations & 5 & $43.80 * *$ & 20.64 & $9.97 * *$ & $4.89 *$ & $4.78 *$ & $14.91 *$ & $16.11 * *$ & $8.79 * *$ & $25.50 * *$ & $9.68 * *$ & $21.85 * *$ \\
\hline Error & 10 & 1.78 & 1.67 & 26.27 & 8.21 & 5.22 & 0.34 & 0.62 & 0.007 & 3.09 & 2.81 & 5.76 \\
\hline Total & 17 & 461.78 & 214.00 & 1694.07 & 308.49 & 180.18 & 30.76 & 60.15 & 0.39 & 432.56 & 166.81 & 703.07 \\
\hline
\end{tabular}

*significant at $\mathrm{t}=0.025 ; \mathrm{ns}=$ non-significant; $\mathrm{DF}=$ degree of freedom

Table 2. Analysis of variance for yield and its related traits in Faisalabad-08 $\times$ DH-60 cross

\begin{tabular}{|c|c|c|c|c|c|c|c|c|c|c|c|c|}
\hline S.O.V & DF & $\begin{array}{l}\text { Days to } \\
\text { heading }\end{array}$ & $\begin{array}{l}\text { Days to } \\
\text { maturity }\end{array}$ & $\begin{array}{l}\text { Plant } \\
\text { height }\end{array}$ & $\begin{array}{l}\text { Peduncle } \\
\text { length }\end{array}$ & $\begin{array}{c}\text { No. of } \\
\text { tillers/ } \\
\text { plant }\end{array}$ & $\begin{array}{l}\text { No. of } \\
\text { spikelet/ } \\
\text { spike }\end{array}$ & $\begin{array}{c}\text { No. of } \\
\text { grains/ } \\
\text { spike }\end{array}$ & $\begin{array}{c}1000- \\
\text { grain wt. }\end{array}$ & $\begin{array}{l}\text { Spike } \\
\text { length }\end{array}$ & $\begin{array}{c}\text { Grain } \\
\text { yield/plant }\end{array}$ & $\begin{array}{c}\text { Spike } \\
\text { density }\end{array}$ \\
\hline Blocks & 2 & $1.63^{\mathrm{ns}}$ & $0.86^{\mathrm{ns}}$ & $20.25 * *$ & $2.16^{\mathrm{ns}}$ & $0.17^{\mathrm{ns}}$ & $8.40 * *$ & $0.73^{\text {ns }}$ & $0.28^{\mathrm{ns}}$ & $3.70^{\mathrm{ns}}$ & $5.93 *$ & $0.42^{\mathrm{ns}}$ \\
\hline Generations & 5 & $32.88 * *$ & $41.42 * *$ & $7.01 *$ & $12.69 * *$ & $8.63 * *$ & $12.65 * *$ & $15.43 * *$ & $5.45^{* *}$ & $7.98 * *$ & $12.46^{* *}$ & $41.42 * *$ \\
\hline Error & 10 & 6.83 & 6.25 & 18.07 & 8.99 & 3.54 & 0.32 & 12.77 & 5.88 & 0.53 & 2.62 & 0.004 \\
\hline Total & 17 & 1214 & 1368.94 & 2267.62 & 699.67 & 189.49 & 28.74 & 1131.35 & 222.52 & 30.36 & 220.93 & 0.72 \\
\hline
\end{tabular}

*significant at $\mathrm{t}=0.025 ; \mathrm{ns}=$ non-significant; $\mathrm{DF}=$ degree of freedom

Table 3. Scaling tests for yield and its related traits in Mairaj- $08 \times$ Blue silver cross

\begin{tabular}{|c|c|c|c|c|c|c|c|c|c|c|c|c|}
\hline $\begin{array}{l}\text { Scaling } \\
\text { tests }\end{array}$ & DF & $\begin{array}{l}\text { Days to } \\
\text { heading }\end{array}$ & $\begin{array}{l}\text { Days to } \\
\text { maturity }\end{array}$ & $\begin{array}{c}\text { Plant } \\
\text { height }\end{array}$ & $\begin{array}{l}\text { No. of } \\
\text { tillers } \\
\text { /plant }\end{array}$ & $\begin{array}{l}\text { Peduncle } \\
\text { length }\end{array}$ & $\begin{array}{l}\text { Spike } \\
\text { length }\end{array}$ & $\begin{array}{c}\text { No. of } \\
\text { spikelet } \\
\text { /spike }\end{array}$ & $\begin{array}{c}\text { Spike } \\
\text { density }\end{array}$ & $\begin{array}{c}\text { No. of } \\
\text { grains/ } \\
\text { spike }\end{array}$ & $\begin{array}{c}\text { 1000- } \\
\text { grains } \\
\text { wt. }\end{array}$ & $\begin{array}{c}\text { Grain } \\
\text { yield } \\
\text { /plant }\end{array}$ \\
\hline $\mathrm{A}$ & 89 & $12.91 *$ & $27.03 *$ & $5.96^{*}$ & $-2.15 *$ & $4.95 *$ & $2.42 *$ & $4.43 *$ & $3.04 *$ & $1.67^{\mathrm{ns}}$ & $0.13^{\mathrm{ns}}$ & $2.64 *$ \\
\hline B & 89 & $23.33 *$ & $14.61 *$ & $1.12^{\mathrm{ns}}$ & $-5.64 *$ & $1.29^{\mathrm{ns}}$ & $-3.20^{*}$ & $2.68 *$ & $11.05^{*}$ & $1.25^{\mathrm{ns}}$ & $0.80^{\mathrm{ns}}$ & $1.27^{\mathrm{ns}}$ \\
\hline $\mathrm{C}$ & 239 & $5.61 *$ & 0 & $13.57 *$ & $-2.32 *$ & $-1.45^{\mathrm{ns}}$ & $8.41 *$ & $9.63 *$ & $-5.21 *$ & $-2.21 *$ & $0.57^{\mathrm{ns}}$ & $6.30 *$ \\
\hline D & 209 & $-24.24 *$ & $-19.83 *$ & $3.62 *$ & $3.24 *$ & $-5.80 *$ & $8.13 *$ & $2.29 *$ & $-13.88 *$ & $-3.68 *$ & $-0.28^{\mathrm{ns}}$ & $1.84^{\mathrm{ns}}$ \\
\hline
\end{tabular}

$*$ significant at $\mathrm{t}=0.025 ; \mathrm{ns}=$ non-significant $\mathrm{DF}=$ degree of freedom 
Table 4. Scaling tests for yield and its related traits in Faisalabad-08 $\times$ DH-60 cross

\begin{tabular}{|c|c|c|c|c|c|c|c|c|c|c|c|c|}
\hline $\begin{array}{c}\text { Scaling } \\
\text { tests }\end{array}$ & DF & $\begin{array}{l}\text { Days to } \\
\text { heading }\end{array}$ & $\begin{array}{l}\text { Days to } \\
\text { maturity }\end{array}$ & $\begin{array}{c}\text { Plant } \\
\text { height }\end{array}$ & $\begin{array}{l}\text { No. of } \\
\text { tillers } \\
\text { /plant } \\
\end{array}$ & $\begin{array}{c}\text { Peduncle } \\
\text { length }\end{array}$ & $\begin{array}{l}\text { Spike } \\
\text { length }\end{array}$ & $\begin{array}{c}\text { No. of } \\
\text { spikelet } \\
\text { /spike } \\
\end{array}$ & $\begin{array}{c}\text { Spike } \\
\text { density }\end{array}$ & $\begin{array}{c}\begin{array}{c}\text { No. of } \\
\text { grains/ } \\
\text { spike }\end{array} \\
\end{array}$ & $\begin{array}{l}1000- \\
\text { grains } \\
\text { wt. }\end{array}$ & $\begin{array}{c}\text { Grain } \\
\text { yield } \\
\text { /plant }\end{array}$ \\
\hline $\mathrm{A}$ & 89 & $33.91 *$ & $31.14^{*}$ & $-3.24 *$ & $-9.13^{*}$ & $-3.25^{*}$ & $-8.10^{*}$ & $1.12^{\mathrm{ns}}$ & $30.80^{*}$ & $-0.03^{\mathrm{ns}}$ & $0.68^{\mathrm{ns}}$ & $2.39 *$ \\
\hline B & 89 & $18.44 *$ & $19.01 *$ & $-7.44 *$ & $-0.05^{\mathrm{ns}}$ & $-6.67 *$ & $1.52^{\mathrm{ns}}$ & $2.30 *$ & $1.21^{\mathrm{ns}}$ & $2.55^{*}$ & $2.17^{*}$ & $1.56^{\mathrm{ns}}$ \\
\hline $\mathrm{C}$ & 239 & $26.41^{*}$ & $30.34 *$ & $5.96^{*}$ & $-0.70^{\mathrm{ns}}$ & $4.03 *$ & $0.85^{\mathrm{ns}}$ & $3.53 *$ & $7.01 *$ & $4.34 *$ & $2.39 *$ & $4.09 *$ \\
\hline D & 209 & $-1.34^{\mathrm{ns}}$ & $-1.49^{\mathrm{ns}}$ & $11.91^{*}$ & $4.23^{*}$ & $11.26^{*}$ & $5.46^{*}$ & $0.24^{\mathrm{ns}}$ & $-24.38^{*}$ & $1.69^{\mathrm{ns}}$ & $-0.63^{\mathrm{ns}}$ & $1.76^{\mathrm{ns}}$ \\
\hline
\end{tabular}

*significant at $\mathrm{t}=0.025 ; \mathrm{ns}=$ non-significant; $\mathrm{DF}=$ degree of freedom

Table 5. Six-parameter model for estimation of genetic parameters in Mairaj-08 $\times$ Blue silver (1) and Faisalabad-08 $\times$ DH-60 $(2)$ for various plant studied traits

\begin{tabular}{|c|c|c|c|c|c|c|c|}
\hline \multirow[t]{2}{*}{ Plant Traits } & \multirow[t]{2}{*}{ Cross } & \multicolumn{6}{|c|}{ Genetic effects } \\
\hline & & Mean (M) & Additive (D) & $\begin{array}{l}\text { Dominance } \\
(\mathrm{H})\end{array}$ & $\begin{array}{l}\text { Additive } \times \text { Additive } \\
\text { (I) }\end{array}$ & $\begin{array}{l}\text { Additive } \times \text { Dominance } \\
(\mathrm{J})\end{array}$ & $\begin{array}{c}\text { Dominance } \times \text { Domianace } \\
(\mathrm{L})\end{array}$ \\
\hline DF & & 239 & 299 & 629 & 539 & 359 & 629 \\
\hline \multirow[t]{2}{*}{ Days to heading } & 1 & $2234.50^{*}$ & $-4.15^{*}$ & $20.91 *$ & $24.24 *$ & $-3.69 *$ & $-24.98 *$ \\
\hline & 2 & $269.44 *$ & $8.36^{*}$ & $-2.57 *$ & 1.34 & $21.04 *$ & $-18.34 *$ \\
\hline \multirow[t]{2}{*}{ Days to maturity } & 1 & $528.32 *$ & -1.00 & $16.32 *$ & $19.83 *$ & $3.57 *$ & $-26.28 *$ \\
\hline & 2 & $441.44 *$ & $6.71 *$ & $-5.12 *$ & $1.49 *$ & $20.79 *$ & $-18.32 *$ \\
\hline \multirow[t]{2}{*}{ Plant height } & 1 & $134.43^{*}$ & -0.07 & $-3.86^{*}$ & $-3.62 *$ & $3.77 *$ & -0.65 \\
\hline & 2 & $88.82^{*}$ & $-2.56^{*}$ & $-13.03^{*}$ & $-11.91 *$ & $2.76^{*}$ & $10.94 *$ \\
\hline \multirow[t]{2}{*}{$\begin{array}{c}\text { No. of } \\
\text { tillers/plant }\end{array}$} & 1 & $28.38 *$ & $3.52 *$ & $-2.62 *$ & $-3.24 *$ & $2.61 *$ & $4.68 *$ \\
\hline & 2 & $30.67 *$ & $-4.92 *$ & $-3.25^{*}$ & $-4.23 *$ & $-5.40 *$ & $4.93 *$ \\
\hline \multirow[t]{2}{*}{ Peduncle length } & 1 & $89.96^{*}$ & $2.57 *$ & $7.07 *$ & $5.80 *$ & $3.34 *$ & $-5.46^{*}$ \\
\hline & 2 & $70.25^{*}$ & $-3.00 *$ & $-11.50^{*}$ & $-11.27 *$ & $2.83 *$ & $10.19^{*}$ \\
\hline \multirow[t]{2}{*}{ Spike length } & 1 & $79.32 *$ & $3.21 *$ & $-6.28 *$ & $-8.13 *$ & $4.31 *$ & $5.23 *$ \\
\hline & 2 & $114.63 *$ & $-7.67 *$ & $-5.17 *$ & $-5.46^{*}$ & $-7.71 *$ & $5.16^{*}$ \\
\hline \multirow[t]{2}{*}{$\begin{array}{c}\text { Number of } \\
\text { spikelet per spike }\end{array}$} & 1 & $136.42 *$ & $2.36^{*}$ & -1.28 & $-2.29 *$ & -0.09 & -1.17 \\
\hline & 2 & $124.32 *$ & 1.16 & 1.07 & -0.24 & -0.61 & -1.07 \\
\hline
\end{tabular}




\begin{tabular}{|c|c|c|c|c|c|c|c|}
\hline Spike density & 1 & $159.57 *$ & -0.89 & $11.95^{*}$ & $13.87 *$ & $-9.10 *$ & $-13.76^{*}$ \\
\hline & 2 & $1000.90 *$ & $32.84 *$ & $27.17^{*}$ & $24.37 *$ & $22.53^{*}$ & $-25.65 *$ \\
\hline \multirow[t]{2}{*}{$\begin{array}{c}\text { Number of grains } \\
\text { per spike }\end{array}$} & 1 & $46.92 *$ & $2.37 *$ & $4.91^{*}$ & $3.85^{*}$ & 0.20 & $-3.22 *$ \\
\hline & 2 & $65.67 *$ & -1.26 & 0.71 & -1.68 & $-1.97 *$ & -0.02 \\
\hline \multirow[t]{2}{*}{$\begin{array}{c}\text { 1000-grains } \\
\text { weight }\end{array}$} & 1 & $10.24 *$ & $7.07 *$ & $0.99 *$ & & & \\
\hline & 2 & $66.28 *$ & -0.57 & 1.75 & 0.63 & -1.59 & -1.44 \\
\hline \multirow[t]{2}{*}{$\begin{array}{c}\text { Grain yield per } \\
\text { plant }\end{array}$} & 1 & $66.73 *$ & $2.62 *$ & 0.60 & -1.84 & 1.31 & -0.47 \\
\hline & 2 & $20.44 *$ & 1.63 & -0.96 & -1.76 & 0.72 & -0.02 \\
\hline
\end{tabular}

*significant at $\mathrm{t}=0.025 ; \mathrm{ns}=$ non-significant; $\mathrm{DF}=$ degree of freedom

Table 6. Temperature, rain fall and humidity data during wheat growing season at D. G. Khan

\begin{tabular}{|c|c|c|c|c|c|c|c|}
\hline \multirow[t]{2}{*}{ Month } & \multicolumn{2}{|c|}{ Temperature ${ }^{\circ} \mathrm{C}$} & \multicolumn{2}{|c|}{ Relative Humidity } & \multirow[t]{2}{*}{$\begin{array}{l}\text { Screen Pan } \\
\text { Evaluation }\end{array}$} & \multirow[t]{2}{*}{$\begin{array}{l}\text { Wind Speed } \\
(\mathrm{Km} / \mathrm{month})\end{array}$} & \multirow[t]{2}{*}{$\begin{array}{c}\text { Rainfall } \\
(\mathbf{m m})\end{array}$} \\
\hline & Max & Min & 0800hrs & 1400hrs & & & \\
\hline Oct, 2013 & 33 & 21 & 78 & 47 & 4.05 & 46 & 5.5 \\
\hline Nov, 2013 & 26 & 10 & 79 & 41 & 2 & 2 & 6 \\
\hline Dec, 2013 & 22 & 06 & 82 & 51 & 097 & 1.69 & 01 \\
\hline Jan, 2014 & 21 & 4 & 73 & 50 & 1.64 & 1.90 & - \\
\hline Feb, 2014 & 21 & 7 & 82 & 45 & 1.70 & 2.0 & 38 \\
\hline Mar, 2014 & 24 & 12 & 83 & 49 & 2.39 & 2.32 & 50 \\
\hline Apr, 2014 & 31 & 18 & 67 & 44 & 4.30 & 2.63 & 69 \\
\hline May, 2014 & 36 & 22 & 52 & 30 & 6.77 & 2.91 & 8 \\
\hline Average & 27 & 13 & 75 & 45 & 15 & 8 & 25 \\
\hline
\end{tabular}


' $L$ ' type of genetic effect known as dominance $x$ dominance epistasis was found significant for many plant traits in both crosses either positively or negatively. These results are in agreement with findings of [3235] while some researcher found moderate to high environmental variations in 1000-grains weight in wheat for segregating generations revealed that it was under influence of the environmental fluctuations [36].

Difference in signs for " $H$ " and " $L$ " was observed in the results for many plant traits studied and it was proposed that duplicate type of epistasis was involved to control the traits but complementary non-allelic gene interaction was also observed in many plant traits. Results also showed that all studied traits were controlled additive as well as nonadditive genetic effects with higher value of dominance gene effects in cross-1 while many plant traits with greater value of additive gene effects was observed in crossII. Similar findings were given by [37-40]. Table 6 indicated temperature, rain fall and humidity data during wheat growing season at D.G. Khan.

\section{Conclusion}

Results of present study exhibited that genetic variability was found as an important factor for all plat traits like days to heading, days to maturity, spike length, number of spikelets per spike and other plant traits studied in cross Mairaj-08 $\times$ Blue silver except for days to maturity while significant differences were observed in all six generations of Faisalabad- $08 \times \mathrm{DH}-60$ for all studied traits. As all traits exhibited genetically differences for both crosses, so generations mean analysis through scaling tests was functional for estimation of gene action for these traits. Scaling tests (A, B, C and D) in Mairaj-08 $\times$ Blue Silver cross were found to be important for all plant attributes except for 1000-grains weight. So, epistasis played a role in inheritance of these traits. Faisalabad-08 $\times$ DH-60 also exhibited significant scaling tests for most of plant traits and indicated presence of epistasis to control these traits. Similarly, in cross (Mairaj-08 $\times$ Blue Silver), epistasis was prominent in all traits except for 1000-grains weight. While in second cross Faisalabad-08 $\times$ DH-60, epistasis was important to control all traits including 1000-grains weight. As 1000-grains weight is an important yield component which enhance grain yield per plant. So, it is suggested that cross-II (Faisalabad-08 $\times$ DH-60) showed promising performance having plant traits with additive gene effects than dominance type of gene effects and epistasis was controlling the inheritance of plant traits so selection of plants at early generations is effective for improving grain yield and this cross can be utilized in future wheat breeding program.

\section{Authors' contributions}

Envisioned the project, designed and performed the experiment: S Mahpara, ST Hussain \& J Iqbal, Analyzed the data: ST Hussain, S Mahpara \& IR Noorka, Wrote and edited the paper: S Mahpara, ST Hussain \& S Salman.

\section{References}

1. Government of Pakistan (2017). Economic Survey of Pakistan (2016-17). Ministry of Finance, Islamabad, Pakistan.

2. Reynolds M, Calderini D, Condon A \& Vargas M (2007). Association of source/sink traits with yield, biomass and radiation use efficiency among random sister lines from three wheat crosses in a high-yield environment. Journal of Agricultural Science 145: 3-16.

3. Parry MAJ, Madgwick PJ, Carvalho JFC \& Andralojc PJ (2007). Prospects for increasing photosynthesis by overcoming the limitations of Rubisco. Journal of Agricultural Science 145: 31-43.

4. Reynolds M, Foulkes MJ, Slafer GA, Martin PB, Parry A J, Snape JW \& Angus WJ (2009). Raising Yield Potential in Wheat. Journal of Experimental Botany 60(7): 1899-1918. 
5. Singh P (2003). Essentials of Plant Breeding. $3^{\text {rd }}$ ed. Kalyani Publishers, New Dehli, India. Pp: 73.

6. Misra SC, Rao VS, Dixit RN, Surve VD \& Patil VP (1994). Genetic control of yield and its components in bread wheat. Ind J Genet 54: 77-82.

7. Singh RP \& Singh S (1992). Estimation of genetic parameters through generation mean analysis in bread wheat. Ind J Genet 52(4): 369-375.

8. Khalifa MA, Shahaby EM, Ali AA \& Towfelis EM (1997). Inheritance of some physiological traits, yiled and its components in durum wheat.2- grain yield and its components. Assiut J Agric Sci 28(4): 143-162.

9. Bayoumi TY, Eid MH \& Metwali, EM (2008). Application of physiological and biochemical indices as a screening technique for drought tolerance in wheat genotypes. African J Biotech 7(14): 2341-2352.

10. Sharma SN, Sain RS \& Sharma RK (2003). Genetics of spike length in durum wheat. Euphytica 130: 155-161.

11. Steel RGD, Torrie JH \& Discky DA (1997). Principles and procedures of statistics: A biometrical approach, 3rd ed. McGraw Hill Book Co., New York.

12. Mather KV, Jinks JL (1982). Introduction to Biometrical Genetics. Chapman and Hall Ltd., London.

13. Hayman BI (1958).The separation of epistatic from additive and dominance variation in generation means. Heredity 12: 371-391.

14. Mahpara S, Ali Z \& Ahsan M (2008). Combining ability analysis for yield and yield related traits among wheat varieties and their $\mathrm{F}_{1}$ hybrids. Int J Biol Sci 10(6): 599-604.

15. Sami Ullah S, Khan AS \& Ashfaq W (2011). Genetic analysis of physiomorphological traits in spring wheat (Triticum aestivum L.) under water stress conditions. Cereal Res Comm 39(4): 544-550.

16. Jatoi WA, Baloch MJ, Khan NU, Munir M, Khakwani AA, Vesar NF, Panhwar SA \& Gul S (2014). Heterosis for yield and physiological traits in wheat under water stress conditions. The J Anim Pl Sci 24(1): 252-261.

17. Kotal BD, Das A \& Choudhury BK (2010). Genetic variability and association of characters in wheat (Triticum aestivum L.). Asian J Crop Sci 2(3): 155-160.

18. Ahmad F, Khan S, Ahmad SQ, Khan H, Khan A \& Muhammad F (2011). Genetic analysis of some quantitative traits in bread wheat across environments. Afr J Agric Res 6(3): 686-692.

19. Hassan MI, Mohamed EA, El-rawy MA \& Amein KA (2016) Evaluating Interspecific Wheat Hybrids Based on Heat and Drought Stress Tolerance. $J$ Crop Sci Biotech 19 (1): 85-98.

20. Rabbani G, Mahmood A, Shabbir G, Shah KN \& Ud-din N (2011). Gene action in some yield attributes of bread wheat under two water regimes. Pak $J$ Bot 43(2): 1141-1156.

21. Kumar S, Singh SK, Gupta SK, Vishwanath, Yadav P, Kumar S, Kumar J, Bind HN \& Singh L (2017) Combining Ability in Relation to Wheat (Triticum aestivum L.) Breeding Programme under Heat Stress Environment. Int J Curr Microbiol App Sci 6(10): 3065-3073.

22. Ijaz, S., K. Sadia, Aziz-ur-Rehman \& Sanaullah. 2017. Exploitation of Heterosis and Combining Ability Effects in Wheat Breeding. J Agric Res 55(2): 235-247

23. Dodig D, Zoric M, Kobiljski B, Savic J, Kandic V, Quarrie S\& Barnes J (2012). Genetic and association mapping study of wheat agronomic traits under 
contrasting water regimes. Int J Mol Sci 13: 6167-6188.

24. Mahpara S, Ali Z, Farooq J, Hussain S\& Bibi R (2015). Heterosis and heterobeltiosis analysis for spike and its related attributes in different wheat crosses. Pak J Nutr 14(7): 396-400.

25. Mahpara S, Ali Z, Rehmani MIA, Iqbal J \& Shafiq MR (2017). Studies of genetic and combining ability analysis for some physio-morphological traits in spring wheat using $7 \times 7$ diallel crosses. Int J Agric Appl Sci 9(1): 33-40.

26. Mahpara S, Rehmani MIA, Hussain S, Iqbal J, Qureshi MK, Shehzad MA \& Dar JS (2017). Heterosis for some physio-morphological plant traits in spring wheat crosses. Pure and Applied Biology 6(4): 1103-1110.

27. Mahpara S (2008). Biometrical analysis for various plant attributes in spring wheat. Ph.D. thesis, Department of Plant Breeding \& Genetics, University of Agriculture, Faisalabad.

28. Magda E\& El-Rahman A (2013). Estimation of some genetic parameters through generation mean analysis in three bread wheat crosses. Alex J Agric Res 58(3): 183-195.

29. El-Hosary AA, Riad ME, Nagwa RA \& Manal AH (2000). Heterosis and combining ability in durum wheat. Proc. 9th conference, Agron., Minufiya Univ., Sept. 2000: 101-117.

30. Esmail RM \& Khattab SAM (2002). Genetic Behavior of Yield and its Components in Three Bread Wheat Crosses. Minufiya J Agric Res 27(2): 215 $-224$.

31. Salem \& Nagwa RA (2006). Estimation of genetic variance for yield and yield components in two bread wheat crosses. J. Agric. Sci. Mansoura Univ 31(10): 6143-6152.
32. Khattab SAM, Esmail RM \& Al-Ansary AEMF (2010). Genetical analysis of some quantitative traits in bread wheat (Triticum aestivum L.). New York Sci J 3(11): 152-157.

33. Khattab SAM, Shaheen AMA \& Afiah SAN (2001). Genetic behavior of some metric traits in four bread wheat crosses under normal and saline conditions. $J$ Agric Sci Mansoura Univ. 26 (1): 217229.

34. Farag HIA (2009). Inheritance of yield and its components in bread wheat (Triticum aestivum L.) using six parameter model under Ras Sudr conditions. 6th International Plant Breeding Conference, Ismailia, Egypt, 90-112.

35. Amin IA (2013). Genetics behavior of some agronomic traits in two durum wheat crosses under heat stress. Alex $J$ Agric Res 58 (1): 53-66.

36. Said AA (2014). Generation mean analysis in wheat (Triticum aestivum L.) under drought stress conditions. Annals of Agricultural Science 59(2): 177-184.

37. Srivastava RB, Sharma SC \& Yunus M (1992). Additive and non-additive gene effects for yield and yield components in two crosses of wheat (Triticum aestivum L.). Ind J Gene 52(3): 297-301.

38. Salman S1, Khan SJ, Ali S, Marwat Sk, Mahpara S \& Ali Q (2017) Genetic Architecture of 1000-Grain Weight in Triticum aestivum. IJBPAS 6(11): 22602279.

39. Allah SU, Khan AS, Raza A \& Sadique $S$ (2010). Gene action analysis of yield and yield related traits in spring wheat (Triticum aestivum L.). Int J Agri Biol 12(1): 125-128.

40. Anwar J, Akbar M, Hussain M, Asghar S, Ahmad J \& Owais M (2011). Combining ability estimates for grain yield in wheat. J Agric Res 49(4): 437-445. 